\title{
Public Narrative, Collective Action, and Power
}

\section{Citation}

Ganz, Marshall. 2011. "Public Narrative, Collective Action, and Power." In Accountability Through Public Opinion: From Inertia to Public Action, eds. Sina Odugbemi and Taeku Lee: 273-289.

Washington D.C: The World Bank.

\section{Published Version}

10.1596/9780821385050_ch18

\section{Permanent link}

http://nrs.harvard.edu/urn-3:HUL.InstRepos:29314925

\section{Terms of Use}

This article was downloaded from Harvard University's DASH repository, and is made available under the terms and conditions applicable to Other Posted Material, as set forth at http:// nrs.harvard.edu/urn-3:HUL.InstRepos:dash.current.terms-of-use\#LAA

\section{Share Your Story}

The Harvard community has made this article openly available.

Please share how this access benefits you. Submit a story.

Accessibility 


\title{
Public Narrative, Collective Action, and Power
}

\author{
Marshall Ganz
}

The authors of this volume ask how discontented, but compliant, publics can mobilize to demand political change. It is not obvious. Organized collective action to challenge the status quo, as opposed to the occasional outburst of resentment, does not "just happen." Nor does it occur as an automatic response to the availability of tools described elsewhere in this book-citizen report cards, public expenditure tracking, participatory budgeting, social audits, right-to-information acts, and so on. Nor does it arise as a result of a providential convergence of resources and opportunities, as often described by social movement theorists.

Organized collective action challenging the status quo-a social movementrequires leadership that goes far beyond a stereotypical charismatic public persona with whom it is often identified. Unable to rely on established bureaucratic structures for coordination, evaluation, and action, such action depends on voluntary participation, shared commitments, and ongoing motivation. Movements must mobilize under risky conditions not only because wellresourced oppositions often resist their efforts, but also because the undertaking itself is fraught with uncertainty about how-and whether-it can happen in the first place. The capacity of a social movement for effective action depends largely on the depth, breadth, and quality of leadership able to turn opportunity to purpose.

Mobilizing others to achieve purpose under conditions of uncertaintywhat leaders do-challenges the hands, the head, and the heart. As shown in figure 18.1, the challenge of the "hands" is one of action, of learning, of adapting, and of mastering novel skills. The challenge of the head is one of strategy, 
Figure 18.1. Mobilization of Others

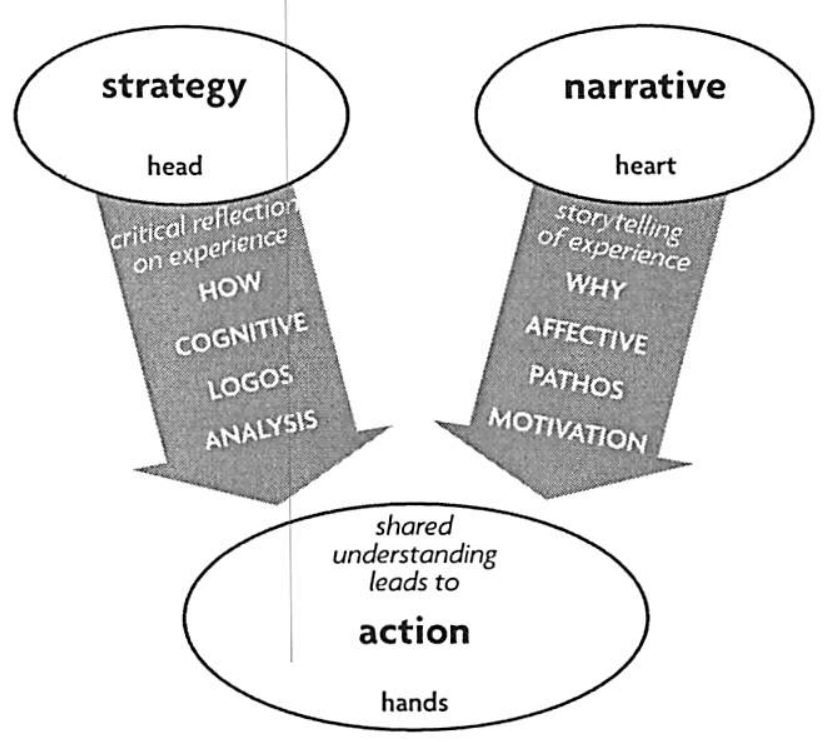

Source: Zac Willette and the author.

imagining how to transform one's resources into the power needed to achieve one's purpose. The challenge of the heart is one of motivation, of urgent need to act, and of hope for success, and the courage to risk it. This is the work of public narrative, the focus of this chapter.

Public narrative is a leadership practice of translating values into action. It is based on the fact that values are experienced emotionally. As such, they are sources of ends worthy of action and the capacity for action. Narrative is the discursive means we use to access values that equip us with the courage to make choices under conditions of uncertainty, to exercise agency. A story is constructed of a plot, character, and moral. A plot is initiated by a challenge that confronts a character with a choice, which, in turn, yields an outcome. Because we identify empathetically with the character, we experience the emotional content of the moment- the values in play, not simply the ideas. Narratives thus become sources of learning, not only for the head, but also for the heart. Public narrative links the three elements of self, us, and now: why I am called, why we are called, and why we are called to act now. Far from new, this framework was articulated by the 1st-century Jerusalem sage, Rabbi Hillel, who, in the Wisdom of the Fathers, asks: If I am not for myself, who will be for me? If I am for myself alone, what am I? If not now, when?'

\section{Two Ways of Knowing: Why and How}

Psychologist Jerome Bruner argues that we interpret the world in two waysthe analytic and the narrative (Bruner 1986). When we cognitively map the 
world, we identify patterns, discern connections, and hypothesize claims and test them-the domain of analysis. But we also map the world affectively by coding experiences, objects, and symbols as good or bad for us, fearful or safe, hopeful or depressing, and so on.

When we consider action in the face of uncertainty, we have to ask ourselves three questions: why must we act, how can we act, and what must we learn to do. Creative analytic thinking can help us answer the how question-how do we use resources efficiently to detect opportunities, compare costs, and so on. We may need to learn new skills to answer the what question.

But to answer the why question-why does it matter, why do we care, why must we risk action-we turn to narrative. The why question is not simply why we think we ought to act, but rather why we must act, what moves us, our motivation, our values. Or, as St. Augustine put it, we find ways of going beyond "knowing" the good as an ought to "loving the good" as a source of motivation. (St. Augustine 1991).

\section{Knowing Why: Emotion, Motivation, and Action}

Because emotions are the medium through which we experience value, they provide us with vital information about the way we ought to live our lives as well as the motivation to live them in that way. To understand motivationthat which inspires action-consider the word emotion and their shared root word motor: to move. Psychologists argue that the information provided by our emotions is partly physiological, as when our respiration changes or our body temperature alters; partly cognitive because we can describe what we feel as fear, love, desire, or joy; and partly behavioral, as when we are moved to advance or to flee, to stand up or to sit down. So, as figure 18.2 shows, our values are sources of the emotional information that can produce action.

Moral philosopher Martha Nussbaum argues that, because we experience values through our emotions, making moral choices in the absence of emotional information is futile (Nussbaum 2001). She is supported by data about the experience of people afflicted with lesions on the amygdale, that part of the brain central to our emotions. When faced with decisions, people with this disability come up with one option after another, but they can never decide because decisions ultimately are based on values. If we cannot experience emotion, we cannot experience the values that orient us to our world. Thus, our readiness to deliberate, our capacity to deliberate successfully, and our ability to act on our decisions rest on how we feel.

\section{Mobilizing Action}

Leadership requires understanding that while some emotions can inhibit mindful action, others can facilitate it. Explaining this relationship, political scientist George Marcus points to two neurophysiologic systems-surveillance 
Figure 18.2. From Values to Action

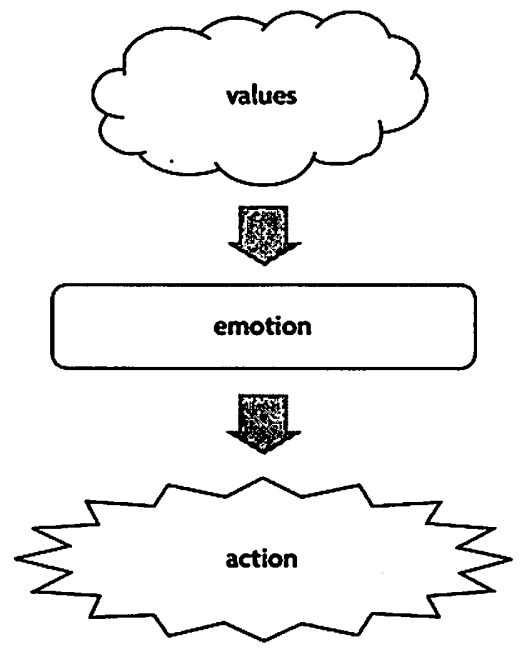

Source: Zac Willette and the author.

and disposition (Marcus 2002). Our surveillance system compares what we expect to see with what we do see, tracking anomalies that, when observed, spark anxiety. Without this emotional cue, we operate out of habit, on autopilot. Anxiety is a way of saying to ourselves, "Hey! Pay attention! There's a bear in the doorway!"

The big question is what we do about that anxiety (so we can figure out what to do about the bear). Our dispositional system operates along a continuum from depression to enthusiasm, or from despair to hope. If we experience anxiety in a despairing mode, our fear will kick in, producing withdrawal, rage, or freezing. However, hope inspires curiosity, leading to exploration that can yield learning and creative problem solving. So our readiness to consider action, our capacity to consider it well, and our ability to act on our consideration rest on how we feel.

Leaders engage others in purposeful action by mobilizing those feelings that facilitate action to trump feelings that inhibit action. We often hold conflicting feelings, some of which are more salient at one time than at another. At times, these feelings may have little to do with the present, but rather are a legacy of emotional lessons we learned long ago. Suppose that, as a four-yearold child, you are playing on a swing set at a park when a bigger child tries to kick you off. You run to your parent for help, but your parent laughs it off. In that moment, you are angry and embarrassed, convinced that your parent does not care. You learned counting on others is a bad idea. Now, as an adult, evaluating what to do about a pay cut, this emotional lesson makes it unlikely that you will join other workers to protest. You fear counting on others; you may even tell yourself you deserved that pay cut. And if you are still in the grips 
of that fear when an organizer comes along and tells you that, with a union, you could keep the employer from cutting your pay, you may see that organizer as a threat. Similarly, the value some people place on not upsetting the boss (teacher, parent, or employer) because of their dependency on that boss may conflict with the value they place on self-respect when the boss does something that violates their sense of self-respect. One person may become angry enough to challenge his or her boss; another may decide to "swallow their pride" or will resist the organizer who points out the conflict. Any resolution can be costly, but one may serve an individual's interests better than another.

\section{Action Inhibitors and Action Facilitators}

So the exercise of leadership often requires engaging people in an emotional dialogue, drawing on one set of emotions (or values) that are grounded in one set of experiences to counter another set of emotions (or values) that are grounded in different experiences-a dialogue of the heart. This dialogue of the heart, far from being irrational, can restore choices that have been abandoned in despair.

As shown in figure 18.3, the major "action inhibitor" is inertia-operating by habit and not paying attention. We process most of the information that comes our way on "autopilot," and we respond as programmed. For much of what we do, this is efficient. If something new is going on, however-something

Figure 18.3. Motivating Action

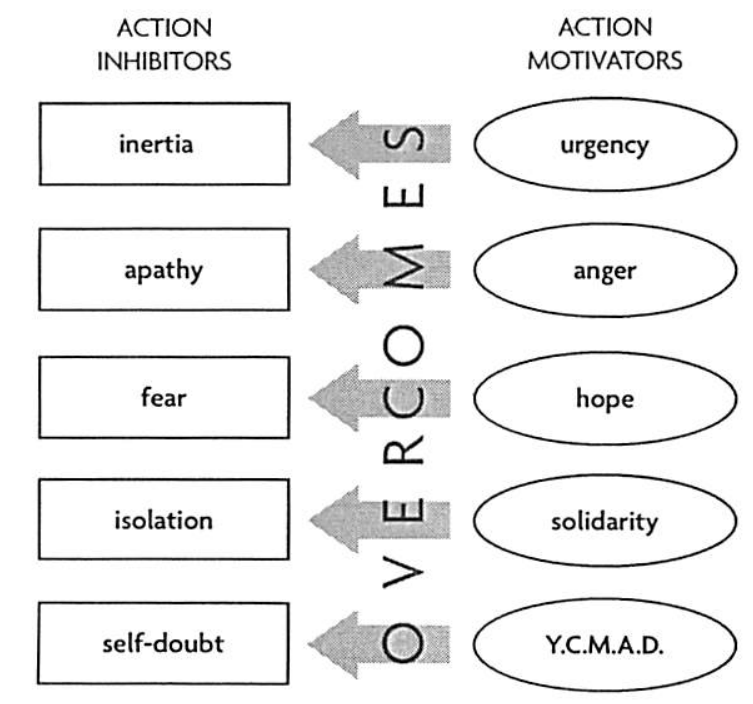

Source: Zac Willette and the author. Note: Y.C.M.A.D. = You Can Make A Difference. 
that might pose a threat or hold out promise-and we stay on autopilot, we may not only miss an opportunity, but also wind up in real trouble.

We can counter inertia with urgency. Urgency can capture our attention, creating the space for new action. But it is less about time than about priority. My need to complete a problem set due tomorrow supplants a more important need to figure out what to do with the rest of life. An urgent need to attend to a critically ill family member supplants an important need to attend the next business meeting.

Commitment and concentration of energy are required to launch anything new, and creating a sense of urgency often is a critical way to get the commitment that is required. Imagine that someone calls you and says that he is recruiting for a 100-year plan to change the world. This is the beginning, and he will call a meeting sometime over the next six months. Would you be interested in going to that meeting, whenever it happens? However, what if someone calls about an election you care about, with news that the campaign has to contact 3,000 targeted voters before Election Day, just one week away? This person tells you that if 220 volunteers contact 20 voters each, they can reach all the voters and bring this election home - that if you come to the headquarters at 6:00 tonight, you will meet the other volunteers and learn how to reach 20 key voters in your neighborhood. Are you interested? Urgency recognizes that "time is like an arrow." Because launching anything new requires commitment and intense effort, urgency is often the way to make it happen.

What about inertia's first cousin, apathy? One way to counter apathy is with anger-not rage, but outrage or indignation with injustice. Anger often grows out of experience of a contrast between the world as it is and the world as it ought to be, how we feel when our moral order has been violated (Alinsky 1971). Sociologist Bill Gamson describes this as using an "injustice frame" to counter a "legitimacy frame" (Gamson 1992). As scholars of "moral economy" have taught us, people rarely mobilize to protest inequality as such, but they do mobilize to protest "unjust" inequality (Scott 1976). In other words, our values, moral traditions, and sense of personal dignity function as critical sources of the motivation to act. This is one reason that organizing is so deeply rooted in moral traditions.

Where can we find the courage to act in spite of our fear? Trying to eliminate that to which we react fearfully is a fool's errand because it locates the source of our fear outside ourselves, rather than within our hearts. However, trying to make ourselves "fearless" is counterproductive if we wind up acting more out of "nerve than brain." Leaders sometimes prepare others for fear by warning them that the opposition will threaten them with this and woo them with that. The fact that these behaviors are expected reveals the opposition as more predictable and, thus, less to be feared.

What can we do about fear? A choice to act in spite of fear is the meaning of courage. Of all the emotions that help us find courage, perhaps most important 
is hope. So where do you go to get some hope? One source of hope is experience of a "credible solution," not only reports of success elsewhere, but also direct experience of small successes and small victories. A source of hope for many people is in their faith tradition, grounded in spiritual beliefs, cultural traditions, and moral understandings. Many of the great social movementsGandhi, civil rights, and Solidarity-drew strength from religious traditions, and much of today's organizing is grounded in faith communities.

Relationships offer another source of hope. We all know people who inspire hopefulness just by being around them. "Charisma" can be seen as the capacity to inspire hope in others, inspiring others to believe in themselves. Many people have charisma, but some of us need to be encouraged to use it. Just as religious belief requires a "leap of faith," Cornel West argues that politics requires a "leap of hope" (West 1994). More philosophically, Moses Maimonides, the Jewish scholar of the 15th century, argued that hope is belief in the "plausibility of the possible" as opposed to the "necessity of the probable." And psychologists who explore the role of "positive emotions" give particular attention to the "psychology of hope" (Seligman and Csikszentmihali 2000). In concert with confidence and solidarity, hope can move us to act.

We can counter feelings of isolation with the experience of belovedness or solidarity. This is the role of mass meetings, singing, common dress, and shared language. This is why developing relationships with the people whom we hope to mobilize is important. Because of the snowball effect, it is much easier to get people to join others who are already active.

Finally, one of the biggest inhibitors is self-doubt: I cannot do it. People like me cannot do it. We are not qualified, and so on. When we feel isolated, we fail to appreciate the interests we share with others, we are unable to access our common resources, we have no sense of a shared identity, and we feel powerless. We can counter self-doubt with YCMAD: You Can Make A Difference. The best way to inspire this belief is to frame what you do around what people can do, not what they cannot do. If you design a plan calling for each new volunteer to recruit 100 people, and you provide no leads, training, or coaching, you will only create deeper feelings of self-doubt. It is also important to recognize specific people for specific contributions at specific times and in specific ways. Recognition must be based on real accomplishment, however, not empty flattery. The idea is to spread accomplishment around and then recognize people for those accomplishments. There is no recognition without personal accountability. Requiring accountability does not show lack of trust, but is evidence that what one is doing really matters. Have you ever volunteered to walk a precinct in a campaign? You are given a packet with a voter list and told to mark the responses on the list and to bring it back when you are done. What happens if you go out for four hours, do a conscientious job, and return to headquarters ready to report, only to hear, "Oh, thanks a lot. Just throw it over there in the corner. See you next week." What about all your work? Did it not 
matter enough for anyone to debrief you about it, let alone mark it on a wall chart and try to learn from it? Do you think you will go back "next week?"

\section{Telling Your Public Story}

Storytelling is the discursive form through which we translate our values into the motivation to act. As shown in figure 18.4, a story is crafted of just three elements: plot, character, and moral. The effect depends on the setting: who tells the story, who listens, where they are, why they are there, and when.

\section{Plot}

A plot engages us, captures our interest, and makes us pay attention. "I got up this morning, had breakfast, and came to school." Is that a plot? Why? Why not?

How about the following: "I was having breakfast this morning when I heard a loud screeching coming from the roof. At that very moment, I looked outside to where my car was parked, but it was gone!" Now what is going on? What is the difference?

A story begins. An actor is moving toward a desired goal. Then some kind of challenge appears. The plan is suddenly up in the air. The actor must figure out what to do. This is when we get interested. We want to find out what happens.

Why do we care?

Figure 18.4. Elements of a Story

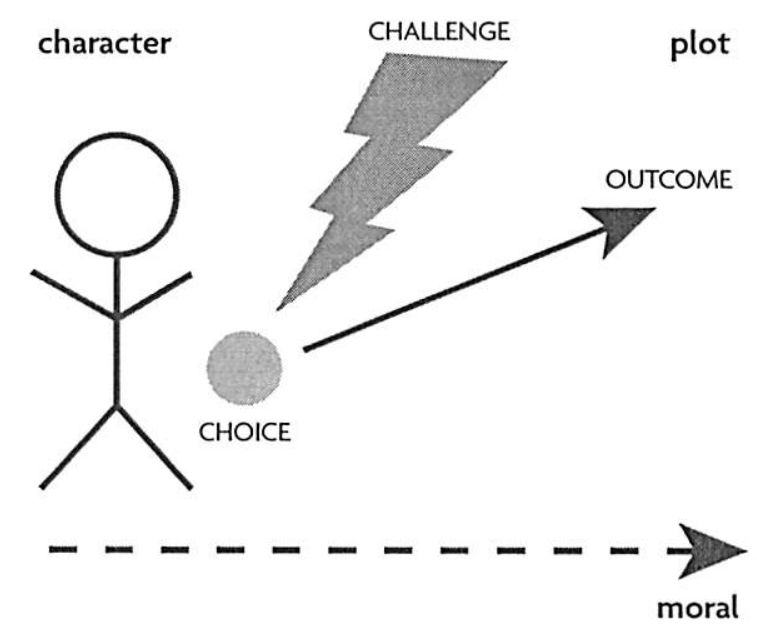

Narrative Structure

Source: Zac Willette and the author. 
Dealing with the unexpected-small and large-defines the texture of our lives. No more tickets at the movie theater. You are about to lose your job. Our marriage is on the verge of break-up. We are constantly faced with the unexpected, and what we are going to do. What is the source of the greatest uncertainty around us? Other people. The subject of most stories is about how to interact with other people.

As human beings, we make choices in the present, based on remembering the past and imagining the future. This is what it means to be an agent. When we act out of habit, however, we do not choose; we just follow the routine. It is only when the routines break down, when the guidelines are unclear, when no one can tell us what to do, that we make real choices and become the creators of our own lives, communities, and futures. Then we become the agents of our own fate. These moments can be as frightening as they are exhilarating.

A plot consists of just three elements: a challenge, a choice, and an outcome. Attending to a plot is how we learn to deal with the unpredictable. Researchers report that most of the time that parents spend with their children is in storytelling-stories of the family, the child's stories, stories of the neighbors. Bruner (1986) describes this as agency training: the way we learn how to process choices in the face of uncertainty. Because our curiosity about the unexpected is infinite, we invest billions of dollars and countless hours in films, literature, and sports events, not to mention religious practices, cultural activities, and national celebrations.

\section{Character}

Although a story requires a plot, it works only if we can identify with a character. Through our empathetic identification with a protagonist, we experience the emotional content of the story. That is how we learn what the story has to teach our hearts, not only our heads. As Aristotle wrote of Greek tragedy in The Poetics, this is how the protagonist's experience can touch us and, perhaps, open our eyes. Arguments persuade with evidence, logic, and data. Stories persuade by this empathetic identification. Have you ever been to a movie where you could not identify with any of the characters? You found it boring. Sometimes we identify with protagonists who are only vaguely "like us"-like the road runner (if not the coyote) in the cartoons. Other times, we identify with protagonists who are very much like us-as in stories about friends, relatives, neighbors. Sometimes the protagonists of a story are $u s$, as when we find ourselves in the midst of an unfolding story in which we are the authors of the outcome.

\section{Moral}

Stories teach. We have all heard the ending "and that is the moral of the story." Have you ever been at a party where someone starts telling a story and goes 
on ... and on ... and on ... ? Someone may say (or want to say), "Get to the point!" We deploy stories to make a point, and to evoke a response.

The moral of a successful story is felt understanding, not simply conceptual understanding. When stated only conceptually, many a moral becomes a banality. We do not retell the story of David and Goliath because it teaches us how to vanquish giants. What the story teaches is that a "little guy"-with courage, resourcefulness, and imagination — can beat a "big guy," especially one with Goliath's arrogance. A fearful character, out of anger, acts courageously and emerges victorious. We feel David's fear, anger, and courage, and we feel hopeful for our own lives because he is victorious. Stories thus teach how to manage our emotions when challenged-how to be courageous, keep our cool, and trust our imagination - rather than the specific tactics to use in any one case.

Stories teach us how to act in the "right" way. They are not simply examples and illustrations. When stories are well told, we experience the point, and we feel hope. It is that experience, not the words as such, that can move us to action, because sometimes that is the point-we have to act.

\section{Setting}

Stories are told. They are not a disembodied string of words, images, and phrases. They are not messages, sound bites, or brands, although these rhetorical fragments may reference a story. Storytelling is fundamentally relational.

As we listen, we evaluate the story, and we find it more or less easy to enter, depending on the storyteller. Is it his or her story? We hear it one way. Is it the story of a friend, a colleague, or a family member? We hear it another way. Is it a story without time, place, or specificity? We step back. Is it a story we share, perhaps a Bible story? Perhaps we draw closer to one another. Storytelling is how we interact with each other about values-how we share experiences with each other, counsel each other, comfort each other, and inspire each other to action.

\section{Public Narrative: Story of Self-Story of Us-Story of Now}

Leadership, especially leadership on behalf of social change, often requires telling a new public story, or adapting an old one: a story of self, a story of us, and a story of now. As shown in figure 18.5, story of self communicates the values that move us to lead. A story of us communicates values shared by those whom you hope to motivate to join us. And a story of now communicates the urgent challenge to those values that demands action now. Participating in a social action not only often involves a rearticulating of one's story of self, us, and now, but also marks an entry into a world of uncertainty so daunting that access to sources of hope is essential. To illustrate, I'll draw examples from the first seven minutes of then Senator Barack Obama's speech to the Democratic National Convention in July 2004. 
Figure 18.5. Self, Us, Now

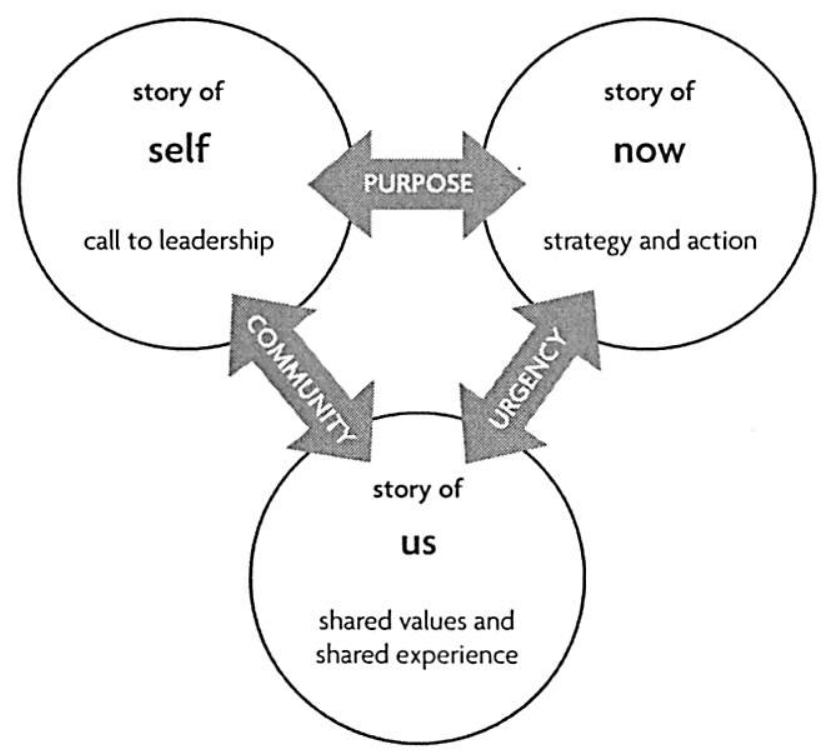

Public Narrative

Source: Zac Willette and the author.

\section{Story of Self}

Telling one's Story of Self is a way to share the values that define who you arenot as abstract principles, but as lived experience. We construct stories of self around choice points-moments when we faced a challenge, made a choice, experienced an outcome, and learned a moral. We communicate values that motivate us by selecting from among those choice points, and recounting what happened. Because storytelling is a social transaction, we engage our listener's memories as well as our own as we learn to adapt our story of self in response to feedback so the communication is successful. Similarly, like the response to the Yiddish riddle that asks who discovered water- "I don't know, but it wasn't a fish"- the other person often can "connect the dots" that we may not have connected because we are so within our own story that we have not learned to articulate them.

We construct our identity, in other words, as our story. What is utterly unique about each of is not a combination of the categories (race, gender, class, profession, and marital status) that include us, but rather, our journey, our way through life, our personal text from which each of us can teach (Hammack 2008).

A story is like a poem. A poem moves not by how long it is, nor by how eloquent or complicated. A story or poem moves by evoking an experience or moment through which we grasp the feeling or insight the poet communicates. Because we are gifted with episodic memory, based on our ability to 
visualize past experience, we can imagine ourselves in the scene described (Tulving 2002). The more specific the details we choose to recount, the more we can move our listeners, the more powerfully we can articulate our values, what moral philosopher Charles Taylor calls our "moral sources." (Taylor 1989, p. 91). Like a poem, a story can open a portal to the transcendent. Telling about a story is different from telling a story. When we tell a story, we enable the listener to enter its time and place with us, see what we see, hear what we hear, feel what we feel. An actor friend once told me the key was to speak entirely in the present tense and avoid using the word "and": I step into the room. It is dark. I hear a sound. Etc.

Some of us may think our personal stories don't matter, that others won't care or that we should not talk about ourselves so much. On the contrary, if we do public work we have a responsibility to give a public account of ourselves: where we came from, why we do what we do, and where we think we're going. In a role of public leadership, we really don't have a choice about telling our story of self. If we don't author our story, others will. And they may tell our story in ways that we may not like, not because they are malevolent, but because others try to make sense of who by drawing on their experience of people whom they consider to be like us. Aristotle argued that rhetoric has three components-logos, pathos, and ethos-and this is ethos. The logos is the logic of the argument. The pathos is the feeling the argument evokes. The ethos is the credibility of the person who makes the argument-his or her story of self.

Social movements are often the "crucibles" within which participants learn to tell new stories of self as we interact with other participants. Stories of self can be challenging because participation in social change is often prompted by a "prophetic" combination of criticality and hope. In personal terms, this means that most participants have stories of both the world's pain and the world's hope. And if we haven't talked about our stories of pain very much, it can take a while to learn to manage it. But if others try to make sense of why we are doing what we are doing and we leave this piece out, our account will lack authenticity, raising questions about the rest of the story.

In the early days of the women's movement, people participated in "consciousness raising" group conversations that mediated changes in their stories of self, who they were, as a woman. Stories of pain could be shared, but so could stories of hope (Polletta 2006). In the civil rights movement, blacks living in the Deep South who feared claiming the right to vote had to encourage one another to find the courage to make the claim, which, once made, began to alter how they thought of themselves and how they could interact with their children, as well as with white people, and each other. (Cuoto 1993).

In Senator Obama's "story of self," he recounts three key choice points: his grandfather's decision to send his son to America to study; his parents' "improbable" decision to marry; and his parents" decision to name him Barack ("blessing"), an expression of faith in a tolerant and generous America. He also 
references his grandfather's choice to enlist and serve in "Patton's army" and his grandmother's choice to "work on a bomber assembly line AND raise a family." Each choice communicates courage, hope, and caring. He tells us nothing of his resumé, preferring to introduce himself by telling us where he came from, and who made him the person that he is, so that we might have an idea of where he is going.

\section{Story of Us}

A public story is not only an account of the speaker's personal experience. All self stories are "nested," including fragments of other stories drawn from our culture, our faith, our parents, our friends, the movies we have seen, and the books we have read. Although individuals have their own stories, communities, movements, organizations, and nations weave collective stories out of distinct threads. Our individual threads intersected on the day that John F. Kennedy was assassinated or the day we saw the planes hit the Twin Towers. We shared a crisis, and we learned the morals about how we are to act and how life is to be lived. Points of intersection become the focus of a shared storythe way we link individual threads into a common weave. A Story of Us brings forward the values that move us as a community.

How does the storyteller become part of this larger story? Learning to tell a story of us requires deciding who the "us" is - which values shape that identity and which are most relevant to the situation at hand. Stories then not only teach us how to live, but also teach us how to distinguish who "we" are from "others," reducing uncertainty about what to expect from our community. In the midst of treacherous weather, earthquakes, disease, and other environmental sources of great unpredictability, the behavior, actions, and reactions of the people among whom we live, and our shared stock of stories, give us greater safety.

Our cultures are repositories of stories. Community stories about challenges we have faced, why we stood up to them-our values and our shared goals-and how we overcame them are woven throughout our political beliefs and religious traditions. We tell community stories again and again as folk sayings, popular songs, religious rituals, and community celebrations (for example, Easter, Passover, and the 4th of July). Just like individual stories, collective stories can inspire hope or generate despair. We also weave new stories from old ones. The Exodus story, for example, served the Puritans when they colonized North America, but it also served Southern blacks claiming their civil rights in the freedom movement (MacIntyre 2001).

Organizations that lack a "story" lack an identity, a culture, core values that can be articulated and drawn on to motivate. Leaders learn to tell the story of us-the story of their organization-by identifying the "choice points" of the organization's journey, recounting experiences that communicate the values embedded in the work of the organization. 
As figure 18.5 shows, our stories of self overlap with our stories of us. We participate in many us's: family, community, faith, organization, profession, nation, or movement. A story of us expresses the values, the experiences, shared by the us we hope to evoke at the time. A story of "us" not only articulates the values of our community, but also can distinguish our community from another, thus reducing uncertainty about what to expect from those with whom we interact. Social scientists often describe a "story of us" as a collective identity (Somers 1992, 1994).

For a collection of people to become an "us" requires a storyteller, an interpreter of shared experience. In a workplace, for example, people who work beside one another but interact little, don't linger after work, don't arrive early, and don't eat together never develop a story of us. In a social movement, the interpretation of the movement's new experience is a critical leadership function. And, like the story of self, it is built from the choice points-the founding, the choices made, the challenges faced, the outcomes, and the lessons it learned.

In Senator Obama's speech, he moves into his "story of us" when he declares, "My story is part of the American story," and proceeds to list values he shares with his listeners-the people in the room, the people watching on television, the people who will read about it the next day. And he begins by going back to the beginning, to choices made by the founders to begin this nation, a beginning that he locates in the Declaration of Independence-a repository of the value of equality.

\section{Story of Now}

Stories of Now articulate the challenges we face now, the choices we are called upon to make, and the meaning of making the right choice. Stories of Now are set in the past, present, and future. The challenge is now; we are called on to act because of our legacy and who we have become, and the action that we take now can shape our desired future.

These are stories in which we are the protagonists. We face a crisis, a challenge. It is our choice to make. We have a story of hope, if we make the right choice. The storyteller among us whom we have authorized to "narrativize" this moment finds a way to articulate our crisis and challenge as a choice, reminds us of our moral resources (our stories-stories of our family, our community, our culture, and our faith), and offers a hopeful vision we can share as we take our first steps on the journey.

A story of now articulates an urgent challenge- - or threat-to the values that we share that demands action now. What choice must we make? What is at risk? And where's the hope? In a story of now, we are the protagonists and it is our choices that shape the outcome. We draw on our "moral sources" to find the courage, hope, empathy perhaps to respond. A most powerful articulation of a story of now was Dr. Martin Luther King's speech delivered in Washington, D.C., on August 23, 1963, often recalled as the "I Have a Dream" speech. People 
often forget that what preceded the dream was a nightmare: the consequence of white America's failure to make good on its promissory note to African Americans. King argued the moment was possessed of the "fierce urgency of now" because this debt could no longer be postponed (King 1963). If we did not act, the nightmare would only grow worse-for all of us-never to become the dream.

In a story of now, story and strategy overlap because a key element in hope is a strategy-a credible vision of how to get from here to there. The "choice" offered cannot be something such as "we must all choose to be better people" or "we must all choose to do any one of this list of 53 things" (which makes each of them trivial). A meaningful choice is more like "we all must all choose: Do we commit to boycotting the busses until they desegregate or not?" Hope is specific, not abstract. What's the vision? When God inspires the Israelites in Exodus, he doesn't offer a vague hope of "better days," but describes a land "flowing with milk and honey" (Exodus 3:9) and what must be done to get there. A vision of hope can unfold a chapter at a time. It can begin by getting that number of people to show up at a meeting that you committed to do. You can win a "small" victory that shows change is possible. A small victory can become a source of hope if it is interpreted as part of a greater vision. In churches, when people have a "new story" to tell about themselves, it is often in the form of "testimony"- a person sharing an account of moving from despair to hope, the significance of the experience strengthened by the telling of it. Hope is not to be found in lying about the facts, but in the meaning we give to the facts. Shakespeare's "King Henry V" stirs hope in his men's hearts by offering them a different view of themselves. No longer are they a few bedraggled soldiers led by a young and inexperienced king in an obscure corner of France who is about to be wiped out by an overwhelming force. Now they are a "happy few," united with their king in solidarity, holding an opportunity to grasp immortality in their hands, to become legends in their own time-a legacy for their children and grand children (Shakespeare, Henry V, Act IV, Scene 3). This is their time! The story of now is that moment in which story (why) and strategy (how) overlap and in which, as poet Seamus Heaney (1991) writes, "Justice can rise up, and hope and history rhyme." And for the claim to be credible, the action must begin right here, right now, in this room, with action each one of us can take. It's the story of a credible strategy, with an account of how, starting with who and where we are, and how we can, step-by-step, get to where we want to go. Our action can call forth the actions of others, and their actions can call others, and together these actions can carry the day. It's like Pete Seeger's old protest song, "One Man's Hands," which reminds us that the targets of social changefrom prison walls to unaccountable governments-cannot fall at the hands of any one person, but rather require the concerted hands of a collectivity.

Senator Obama moves to his "story of now" with the phrase, "There is more work left to do." After we have shared in the experience of values we identify with America at its best, he confronts us with the fact that they are not realized 
in practice. He then tells stories of specific people in specific places with specific problems. As we identify with each of them, our empathy reminds us of pain we have felt in our own lives. But, he also reminds us, all this could change. And we know it could change. And it could change because we have a way to make the change, if we choose to take it. And that way is to support the election of Senator John Kerry. Although that last part didn't work out, the point is that he concluded his story of now with a very specific choice he calls upon us to make.

Through public narrative, leaders-and participants-can move to action by mobilizing sources of motivation, constructing new shared individual and collective identities, and finding the courage to act.

\section{Celebrations}

We do much of our storytelling in celebrations. A celebration is not a party. It is a way that members of a community come together to honor who they are, what they have done, and where they are going-often symbolically. Celebrations may occur at times of sadness, as well as times of great joy. Celebrations provide rituals that allow us to join in enacting a vision of our community-at least in our hearts. Institutions that retain their vitality are rich in celebrations. In the Church, for example, Mass is "celebrated." Harvard's annual celebration is called Graduation and lasts an entire week.

Storytelling is at its most powerful at beginnings-for individuals, their childhood; for groups, their formation; for movements, their launching; and for nations, their founding. Celebrations are a way we interpret important events, recognize important contributions, acknowledge a common identity, and deepen our sense of community. The way that we interpret these moments begins to establish norms, create expectations, and shape patterns of behavior, which then influence all subsequent development. We draw on them again and again. Nations institutionalize their founding story as a renewable source of guidance and inspiration. Most faith traditions enact a weekly retelling of their story of redemption, usually rooted in their founding. Well-told stories help turn moments of great crises into moments of "new beginnings."

\section{Conclusion}

Narrative allows us to communicate the emotional content of our values. Narrative is not talking "about" values; rather, narrative embodies and communicates those values. It is through the shared experience of our values that we can engage with others; motivate one another to act; and find the courage to take risks, explore possibility, and face the challenges we must face. Public narrative, understood as a leadership art, is thus an invaluable resource to stem the tides of apathy, alienation, cynicism, and defeatism. Stories, strategically told, 
can powerfully rouse a sense of urgency; hope; anger; solidarity; and the belief that individuals, acting in concert, can make a difference.

\section{Note}

1. As noted by Pirkei Avot in Sayings of the Jewish Fathers (also translated as "Ethics of the Fathers"). See http://www.sacred-texts.com/jud/sjf/, which is a translation from 1897 by Charles Taylor.

\section{References}

Alinsky, Saul. 1971. Rules for Radicals. New York: Random House.

Bruner, Jerome. 1986. "Two Modes of Thought." In Actual Minds, Possible Worlds, 11-25. Cambridge, MA: Harvard University Press.

Cuoto, Richard A. 1993. "Narrative, Free Space, and Political Leadership in Social Movements." Journal of Politics 55 (1): 57-79.

Gamson, William A. 1992. Talking Politics. New York: Cambridge University Press.

Hammack, Phillip L. 2008. "Narrative and the Cultural Psychology of Identity." Personality and Social Psychology Review 12 (3): 222-47.

Heaney, Seamus. 1991. The Cure at Troy: A Version of Sophocles' Philoctetes. New York: Farrar, Straus, and Giroux.

Hebrew Bible. 1 Samuel 17:4-49 (King James Version).

King, Martin Luther, Jr. "I Have a Dream" (speech, Washington, DC, August 28, 1963).

MacIntyre, Alasdair. 2001. "The Virtues, the Unity of a Human Life, and the Concept of a Tradition." In Memory, Identity, Community: The Idea of Narrative in the Human Sciences, ed. Lewis P. Hinchman and Sandra K. Hinchman, 241-63. Albany, NY: State University of New York Press.

Marcus, George E. 2002. The Sentimental Citizen: Emotion in Democratic Politics. University Park, PA: Penn State University Press.

Nussbaum, Martha. 2001. Upheavals of Thought: The Intelligence of Emotions. New York: Cambridge University Press.

Polletta, Francesca. 2006. "Ways of Knowing and Stories Worth Telling." In It Was Like a Fever: Storytelling in Protest and Politics, 109-140. Chicago: University of Chicago Press.

Scott, James C. 1976. The Moral Economy of the Peasant. New Haven, CT: Yale University Press.

Seligman, Martin E. P., and Mihaly Csikszentmihali. 2000. "Positive Psychology: An Introduction." American Psychologist 55 (1): 5-14.

Shakespeare, William. Henry V, Act IV, Scene 3.

Somers, Margaret. 1992. "Narrativity, Narrative Identity, and Social Action: Rethinking English Working-Class Formation." Social Science History 16 (4): 591-629.

- 1994. "The Narrative Constitution of Identity: A Relational and Network Approach." Theory and Society 23 (5): 605-49.

St. Augustine. 1991. Confessions. Book 8. Translated by Henry Chadwick. New York: Oxford University Press.

Taylor, Charles. 1989. Sources of the Self: The Making of the Modern Identity. Cambridge, MA: Harvard University Press.

Tulving, Endel. 2002. "Episodic Memory: From Mind to Brain." Annual Review of Psychology 53 (2002): 1-25.

West, Cornel. 1994. Race Matters. New York: Vintage Books. 